\title{
Commentary: Prediction of pulmonary root dilatation after Ross operation-The power of protein shake?
}

\author{
Igor E. Konstantinov, MD, PhD, FRACS, ${ }^{\mathrm{a}, \mathrm{b}, \mathrm{c}, \mathrm{d}}$ Federica Caldaroni, MD, ${ }^{\mathrm{a}}$ and Yaroslav Ivanov, MD ${ }^{\mathrm{a}}$
}

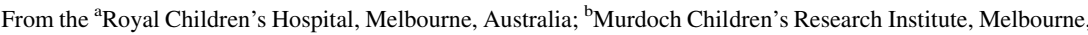
Australia; ${ }^{3}$ University of Melbourne, Melbourne, Australia; and ${ }^{\mathrm{d}}$ Melbourne Children's Centre for Cardiovascular Genomics and Regenerative Medicine, Melbourne, Australia.

Disclosures: Authors have nothing to disclose with regard to commercial support.

Received for publication Aug 2, 2019; accepted for publication Aug 2, 2019; available ahead of print Oct 18, 2019.

Address for reprints: Igor E. Konstantinov, MD, PhD, FRACS, Royal Children's Hospital, Flemington Rd, Parkville, VIC 3052, Australia (E-mail: igor.konstantinov@rch.org.au).

J Thorac Cardiovasc Surg 2020;159:635-6

$0022-5223 / \$ 36.00$

Crown Copyright $@ 2019$ Published by Elsevier Inc. on behalf of The American Association for Thoracic Surgery https://doi.org/10.1016/j.jtcvs.2019.08.023
}

An explosive development of global molecular assessment technology during the recent decades has resulted in the multitude of "-omic" approaches awaiting to be translated into surgical practice. To most surgeons, however, genomics, proteomics, metabolomics, comics, and other "-omics" are of very similar predictive and entertaining value. Namely, often the "-omics" do not predict anything and are somewhat mildly entertaining, at least as far as the surgical outcomes are concerned. This is the current state of affair in surgical "-omics". But for how long? With the rapid refinement of the "-omic" technology, one cannot help wondering what surgical "-omics" may come, and what diagnostic value will come of it.

A novel and fascinating proteomic study reported in this issue of the Journal has been performed by Chiriani and colleagues $^{1}$ in attempt to shed light on the causes of the late autograft failure after the Ross operation. It is indeed unclear why some patients develop autograft failure develop while others do not, even after seemingly identical Ross $_{\text {operations. }}{ }^{2-4}$ Extensive imaging and histologic studies have been performed to determine whether the increase in size of the autograft is due to actual growth of the implanted tissue or rather is merely attributable to tissue stretching. ${ }^{4-6}$ Still, perhaps as a result of the whole galaxy of potential contributing factors, the exact causes behind the autograft failure remain elusive.

To determine this, Chiarini and colleagues ${ }^{1}$ have provided a valuable contribution to the general understanding of this process at the proteomic level. They investigated the changes that occurred in the tunica media of the sinuses of Valsalva of the neoaortic roots in 9 patients who underwent reoperations for autograft failure. Their study highlighted that the pulmonary autograft remodeling with dilatation has a certain protein expression pattern. Interestingly, the protein expression in pulmonary autografts was very different from that observed in the normal aortic root and pulmonary artery. The greatest differences, however,

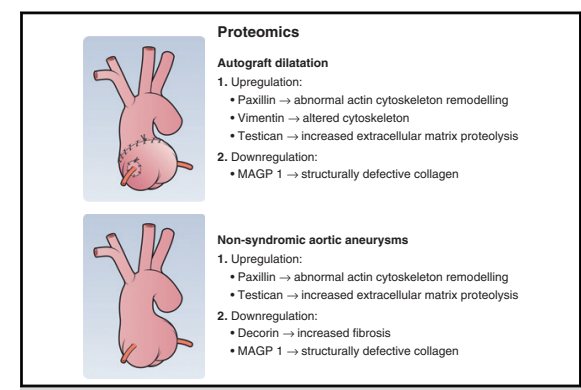

Key proteomic changes after Ross operation are similar to nonsyndromic aortic aneurysms.

Central Message

Proteomic studies may shed light on the causes of late autograft failure.

See Article page 621.

were observed when the autografts were compared with the normal pulmonary arteries. The proteomic changes appear to occur in the extracellular matrix and cytoskeleton, suggesting a maladaptive remodeling of the autograft with progressive loss of elasticity and dilatation of the neoaortic root (Figure 1). The key differentially expressed proteins appeared to be thematically linked to cause extracellular matrix remodeling. The exact causation, however, is impossible to establish. The study raises more questions than it gives answers. Does the same "maladaptive" remodeling occur in nondilated autografts? Is such "maladaptive" remodeling merely a result of systemic pressure applied to the pulmonary autograft?

Embryologically, the aortic and pulmonary roots have the same truncal origin, and thus they likely have similar contents of collagen and elastin fibers and also similar densities of cells. ${ }^{7}$ The fundamental question therefore is what drives genes to express "maladaptive" proteins in a setting of autograft failure. Potentially, there could be many factors responsible for autograft failure, including, but not limited to, age of patients, the nature of aortic valve disease, and technical aspects of the Ross procedure. It has been observed that the risk of autograft failure in younger children is less than that in older children, which may reflect the adaptive capability of autograft to remodel through the "normal" gene expression. ${ }^{8}$ Interestingly, in their study, Chiarini and colleagues ${ }^{1}$ reported a mean age of 37 years for patients who underwent autograft explantation, which may 


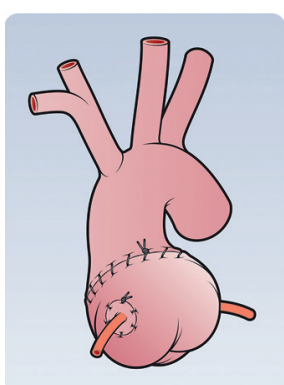

\section{Proteomics}

\section{Autograft dilatation}

1. Upregulation:

- Paxillin $\rightarrow$ abnormal actin cytoskeleton remodelling

- Vimentin $\rightarrow$ altered cytoskeleton

- Testican $\rightarrow$ increased extracellular matrix proteolysis

2. Downregulation:

- MAGP $1 \rightarrow$ structurally defective collagen

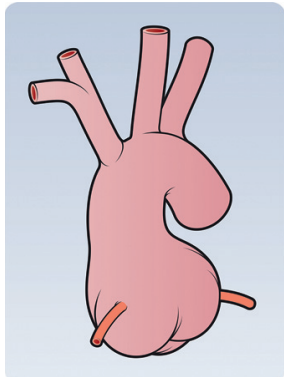

Non-syndromic aortic aneurysms

1. Upregulation:

- Paxillin $\rightarrow$ abnormal actin cytoskeleton remodelling

- Testican $\rightarrow$ increased extracellular matrix proteolysis

2. Downregulation:

- Decorin $\rightarrow$ increased fibrosis

- MAGP $1 \rightarrow$ structurally defective collagen

FIGURE 1. Key proteomic changes in pulmonary autograft dilatation after the Ross operation are similar to those that occur in patients with nonsyndromic aortic aneurysms. MAGP, Microfibril-associated glycoprotein.

reflect the age-related loss of adaptive capability of autograft in older patients.

Furthermore, it appears that patients with bicuspid aortic valve have a higher rate of autograft dysfunction. ${ }^{9}$ Similarly, this may also be a reflection of the anomalous genes expression in the implanted autograft in this subgroup of patients. Importantly, the similar proteomic pathways are activated in patients with nonsyndromic thoracic aneurisms. ${ }^{10}$ At present, neither the proteomics of nondilated pulmonary roots exposed to systemic pressure nor the causation of the "maladaptive" remodeling is fully understood. Nevertheless, it is not entirely inconceivable that the "-omic" technology may potentially evolve into a useful diagnostic tool to identify patients at risk for autograft failure. The current application of proteomics is more of a dream than a surgical reality. It is yet to be seen what dreams may come.

\section{References}

1. Chiriani A, Faggian G, Armato U, Luciani GB. Maladaptive remodeling of pulmonary artery root autografts after Ross procedure: a proteomic study. $J$ Thorac Cardiovasc Surg. 2020;159:621-32.e3.
2. Sievers HH, Stierle U, Petersen M, Klotz S, Richardt D, Diwoky M, et al. Valve performance classification in 630 subcoronary Ross patients over 22 years. $J$ Thorac Cardiovasc Surg. 2018;156:79-86.e2.

3. David TE, Ouzounian M, David CM, Lafreniere-Roula M, Manlhiot C. Late results of the Ross procedure. J Thorac Cardiovasc Surg. 2019;157:201-8.

4. Solymar L, Südow G, Holmgren D. Increase in size of the pulmonary autograft after the Ross operation in children: growth or dilation? J Thorac Cardiovasc Surg. 2000;119:4-9.

5. Ando Y, Ochiai Y, Tokunaga S, Hisahara M, Baba H, Miyagi C, et al. Size and stiffness of the pulmonary autograft after the Ross procedure in children. Pediatr Cardiol. 2019;40:776-83.

6. Schoof PH, Takkenberg JJM, van Suylen RJ, Zondervan PE, Hazekamp MG, Dion RA, et al. Degeneration of the pulmonary autograft: an explant study. $J$ Thorac Cardiovasc Surg. 2006;132:1426-32.

7. Aikawa E, Whittaker P, Farber M, Mendelson K, Padera RF, Aikawa M, et al. Human semilunar cardiac valve remodeling by activated cells from fetus to adult: implications for postnatal adaptation, pathology, and tissue engineering. Circulation. 2006;113:1344-52.

8. Lo Rito M, Davies B, Brawn WJ, Jones TJ, Khan N, Stickley J, et al. Comparison of the Ross/Ross-Konno aortic root in children before and after the age of 18 months. Eur J Cardiothorac Surg. 2014;46:450-7.

9. Sharifulin R, Bogachev-Prokophiev A, Zheleznev S, Demin I, Pivkin A, Afanasyev A, et al. Factors impacting long-term pulmonary autograft durability after the Ross procedure. J Thorac Cardiovasc Surg. 2019;157:134-41.e3.

10. Chiarini A, Onorati F, Marconi M, Pasquali A, Patuzzo C, Malashicheva A, et al. Studies on sporadic non-syndromic thoracic aortic aneurysms: II. Alterations of extra-cellular matrix components and focal adhesion proteins. Eur J Prev Cardiol. 2018;25(1 Suppl):51-8. 